\title{
The effect of radiofrequency radiation on DNA and lipid damage in non-pregnant and pregnant rabbits and their newborns
}

\author{
Goknur Guler, Arin Tomruk, Elcin Ozgur and Nesrin Seyhan \\ Department of Biophysics, Medical Faculty Gazi University, Ankara 06500, Turkey; E-mail: gozturk@gazi.edu.tr
}

\begin{abstract}
The concerns of people on possible adverse health effects of radiofrequency radiation (RFR) generated from mobile phones as well as their supporting transmitters (base stations) have increased markedly. RFR effect on oversensitive people, such as pregnant women and their developing fetuses, and older people is another source of concern that should be considered. In this study, oxidative DNA damage and lipid peroxidation levels in the brain tissue of pregnant and non-pregnant New Zealand White rabbits and their newborns exposed to RFR were investigated. Thirteen-month-old rabbits were studied in four groups as non-pregnant-control, non-pregnant-RFR exposed, pregnant-control and pregnant-RFR exposed. They were exposed to RFR (1800 MHz GSM; $14 \mathrm{~V} / \mathrm{m}$ as reference level) for $15 \mathrm{~min} /$ day during 7 days. Malondialdehyde (MDA) and 8-hydroxy-2'-deoxyguanosine (8-OHdG) levels were analyzed. MDA and 8-OHdG levels of non-pregnant and pregnant-RFR exposed animals significantly increased with respect to controls ( $p<0.001$, Mann-Whitney test). No difference was found in the newborns ( $p>0.05$, Mann-Whitney). There exist very few experimental studies on the effects of RFR during pregnancy. It would be beneficial to increase the number of these studies in order to establish international standards for the protection of pregnant women from RFR.
\end{abstract}

Key words: Radiofrequency radiation - Pregnant exposure - MDA - 8-OHdG - Brain

Abbreviations: RFR, radiofrequency radiation; 8-OHdG, 8-hydroxy-2'-deoxyguanosine; dG, deoxyguanosine; MDA, malondialdehyde; IQR, interquartile range

\section{Introduction}

Electromagnetic pollution is one of the main environmental health issues caused by the man-made sources like devices for wireless communication. Base stations used for communication through mobile phones are important sources of radiofrequency radiation (RFR). Public concerns have markedly increased due to the oversensitive people such as pregnant women exposed to RFR. Although two of the most influential guidelines, International Commission on Non-Ionizing Radiation Protection (ICNIRP) and Institute of Electrical and Electronics Engineers (IEEE) limit the maximum levels of RFR exposure to general public and workers, they do not comprise pregnant women and their infants.

Correspondence to: Göknur Güler, Gazi Üniversitesi Tip Fakültesi Biyofizik AbD, Dekanlık Binası 5. Kat 06510 Besevler, Ankara 06500, Turkey

E-mail: gozturk@gazi.edu.tr
Most of the epidemiological and experimental (in vivo/in vitro) studies revealed that different frequency ranges of RFR may induce biological responses concerning the cell proliferation, morphology and apoptosis (Repacholi 1998; Marinelli et al. 2004; Zhao et al. 2007), the membrane structure and function (Phelan et al. 1992; Repacholi 1998) and the breakage of DNA (Lai and Singh 1995, 1996, 1997). DNA damage caused by RFR may trigger cancer development (Hardell et al. 2002, 2003), increase the prevalence of infertility due to the effects of hormonal changes on testis (Fejes et al. 2005; Agarwal et al. 2008) and cause fetal loss and developmental malformations (Heynick and Merritt 2003).

Most of the physiological responses of living organism arise from both localized and whole-body average temperature changes based on carrier frequency of RFR. Besides the changes in maternal colonic temperature, fetal body weight is also used as an indicator to determine the threshold of fetal effects induced by RFR or microwave exposure (Berman et al. 1992). It is reported that maternal rectal temperature of 
the pregnant mice and the pregnant rats exposed to high levels of microwave energy in $2.45 \mathrm{GHz}$ increased whereas the body weight of the offspring decreased (Berman et al. $1981,1982,1984)$. In the present study, rectal temperatures of both non-pregnant group and non-pregnant-RFR exposed group were measured to determine the temperature changes induced by the exposure to the radiation like GSM (global system for mobile communications) signal.

It has been suggested that one of the interaction mechanisms of RFR with biological matter is the biochemical mechanism that is based on the responses caused by activating secondary chemical messengers such as ions, radicals or molecules (Belyaev 2005). Due to the overproduction of free radicals and deficiency in the amounts of antioxidants, the balance between free radicals and antioxidants is disrupted in favor of the free radicals resulting in oxidative and nitrosative damages which are known as oxidative stress or nitrosative stress (Halliwell and Gutteridge 2000). Oxidative stress may result in severe metabolic dysfunctions, including peroxidation of membrane lipids, depletion of nicotine amide nucleotides, rises in intracellular free $\mathrm{Ca}^{2+}$ ions, cytoskeleton disruption and DNA damage. Since repair of almost all of the biomolecules depends on the information coded in the DNA, there is a postulated importance of oxidative DNA damage. 8-hydroxy-2'-deoxyguanosine (8-OHdG) is one of the most frequently used base adducts generated by free radical attacks (Cook et al. 2003). Another metabolic dysfunction of oxidative stress is the peroxidation of lipids. Lipid peroxides, which are formed as a result of complex chain reactions mediated by reactive oxygen species (ROS), are considered to be an important cause of damage to cell membranes. One of the main biomarkers widely used in determination of oxidative destruction on lipids mediated by second messengers is malondialdehyde (MDA) (Nair et al. 1986; Draper and Hadley 1990).
The present study was designed to evaluate the possible biological effects of whole body $1800 \mathrm{MHz}$ GSM-like RFR exposure on brain oxidative DNA damage and lipid peroxidation levels in both non-pregnant and pregnant New Zealand White rabbits and in their newly borns. This study tries to simulate the exposure of non-pregnant and pregnant mobile phone subscribers of the same age during pregnancy and their babies that are exposed to these fields as fetus.

\section{Materials and Methods}

\section{Exposure level and quality control}

GSM-like signals in $1800 \mathrm{MHz}$ frequency were formed by using a signal generator (Agilent Technologies $8648 \mathrm{C}$, $9 \mathrm{kHz}-3.2 \mathrm{GHz}$ ) with the integrated pulse modulation unit and horn antenna (Schwarzbeck, Doppelsteg Breitband Horn antenna BBHA 9120 L3F, 0.5-2.8 GHz) in a shielded room. The generated power was controlled by a spectrum analyzer (Agilent Technologies N9320A, 9 kHz-3 GHz) integrated to the signal generator. The signals were amplitude-modulated by rectangular pulses with a repetition frequency of $217 \mathrm{~Hz}$ and a duty cycle of $1: 8$ (pulse width $0.576 \mathrm{~ms}$ ), corresponding to the dominant modulation component of the GSM.

RFR generator provided $0.1 \mathrm{~W}(20 \mathrm{dBm})$ during the exposure period. The signal was controlled by means of the spectrum analyzer connected to the signal generator, and NARDA EMR 300 and type 26.1 probe were used for measurement of the output radiation. Measurements were taken during the entire experiment and the data was saved in the computer which was connected to the device via fiber optic cable. The evaluated data was $14 \pm 0.5 \mathrm{~V} / \mathrm{m}$ (Figure 1).

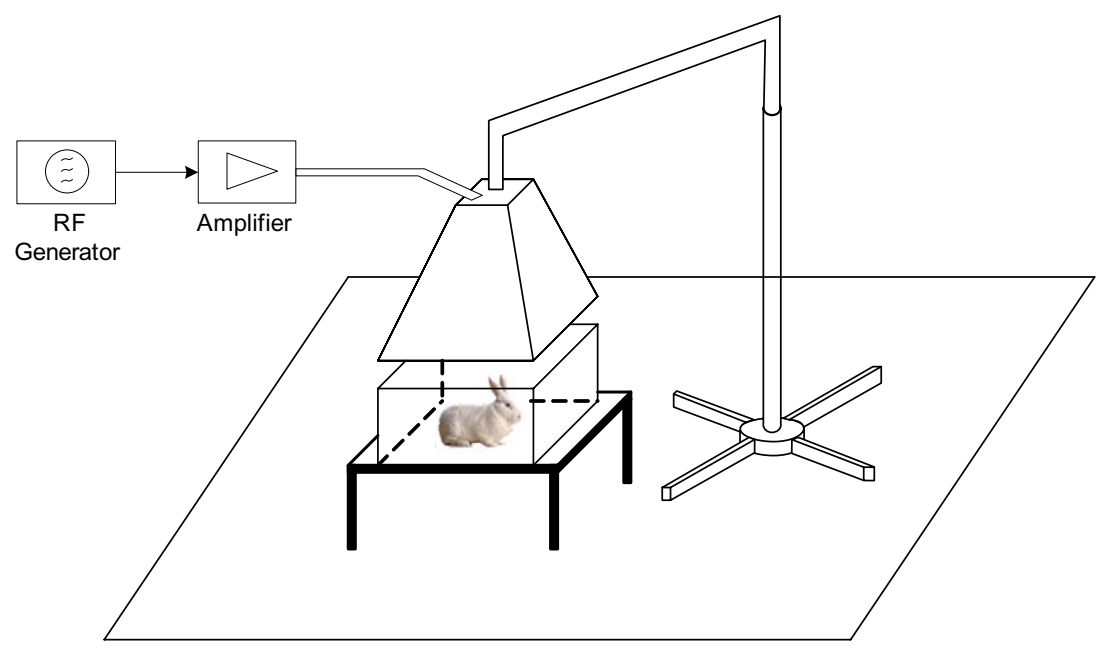

Figure 1. GSM-like RFR exposure system. 


\section{Animals}

New Zealand White rabbits were obtained from the Laboratory Animals Breeding and Experimental Research Center of Gazi University (13-month-old non-pregnant and pregnant rabbits; $n=36$ ). The experimental protocol was reviewed and approved by the Laboratory Animal Care Committee of Gazi University. All the animal procedures were performed in accordance with the approved protocol.

Rabbits were housed under the same conditions in a temperature and humidity-controlled room $\left(20 \pm 1^{\circ} \mathrm{C}, 50 \pm 10 \%\right.$ relative humidity) and $14-16 \mathrm{~h}$ light/dark cycle conditions. Except during exposure periods, tap water and standard pelletized food were provided ad libitum. Coeval pregnant and non-pregnant rabbits were adapted to the laboratory conditions for five days before the experiment. Quality controls were conducted by the veterinarians to verify that rabbits used in this experiment were healthy at all stages of the experiment. The aim of these controls was to check the health condition of the adult rabbits, condition of the gestation and any malformation or prenatal death of the offspring.

In the breeding process, we selected female rabbits that would get pregnant for the fourth time. Because previous experience of being a mother three times leads to obtain high performance in the number of litter. Besides, mothers are then experienced enough to feed and look after their babies. During the mating process, male ratio was kept constant being one male to 10 female rabbits. Pregnancies were verified by abdominal palpation ten days after the process of mating.

Pregnant and non-pregnant rabbits are exposed to RFR in the same conditions for 7 days after the adaptation period. Exposure period was between $15^{\text {th }}$ and $22^{\text {nd }}$ days of the gestation for the pregnant rabbits. After the exposure, rabbits were left on their own without any intervention until gestation period of pregnant rabbits, approximately 30 days is over.

After birth, only one newborn, not exposed to RFR (max. 2 days) was randomly selected from each litter and killed immediately after the anesthesia. The main reason for investigating the newborns was to observe the possible effects of intrauterine RFR exposure (between $15^{\text {th }}$ and $22^{\text {nd }}$ days of the gestational period when the transition from embryogenesis to organogenesis takes place).

Only one animal was placed in each cage during each RFR exposure period because placing more than one animal in a cage would create a stress factor. The rectal temperatures were measured before and after the exposure by digital thermometer (Elite, Istanbul, Turkey) in both non-pregnantcontrol and non-pregnant-RFR exposed rabbits.

\section{Experimental design}

Non-pregnant and pregnant New Zealand White rabbits were randomly divided into four groups. Animals were kept in plexiglass cage since plexiglass is a non-conductive material that is not affected by RFR.

Group I (non-pregnant-control): Each non-pregnant rabbit in sham-exposed group $(n=9)$ was kept in experimental setup for $15 \mathrm{~min} /$ day during 7 days with the device switched-off.

Group II (non-pregnant-RFR exposed): Non-pregnant rabbits in RFR-exposed group $(n=9)$ were exposed individually to $1800 \mathrm{MHz}$ GSM-like RFR for $15 \mathrm{~min}$ /day during 7 days.

Group III (pregnant-control): Pregnant rabbits $(n=9)$ were kept in experimental setup for $15 \mathrm{~min} /$ day during 7 days with the device switched-off.

Group IV (Pregnant-RFR exposed): Pregnant rabbits in RFR-exposed group $(n=9)$ were exposed individually to $1800 \mathrm{MHz}$ GSM-like RFR for $15 \mathrm{~min} /$ day during 7 days.

Newborns $(n=18)$ were also divided into two groups:

Group V (newborns of Group III): Newly born rabbits $(n=9)$ of pregnant-control group.

Group VI (newborns of Group IV): Newly born rabbits $(n=9)$ of pregnant-RFR exposed group. They were exposed to $1800 \mathrm{MHz}$ GSM-like RFR for $15 \mathrm{~min} /$ day during 7 days in the intrauterine period (between $15^{\text {th }}$ and $22^{\text {nd }}$ days of the gestational period).

The day after the last exposure, rabbits were anesthetized with ketamine $(35 \mathrm{mg} / \mathrm{kg}$, intramuscular) and xylazine (5-10 $\mathrm{mg} / \mathrm{kg}$, intramuscular), then killed.

\section{Biochemical analysis}

Brain tissues rinsed with ice-cold buffered saline and stored at $-30^{\circ} \mathrm{C}$ (maximum $10 \mathrm{~h}$ ) for double-blind biochemical analysis. After weighing, the brain was cut into small pieces and then homogenized in four volumes of ice-cold Tris- $\mathrm{HCl}$ buffer ( $50 \mathrm{mmol} / \mathrm{l}, \mathrm{pH} 7.4$ ) by using homogenizer (Disperser T10 basic D-79219, IKA-WERKE, GmbH, Staufer).

MDA levels were analyzed in the brain homogenate. The principle of MDA determination method is based on the spectrophotometric measurement of the color generated by the reaction of thiobarbituric acid (TBA) with MDA (Draper and Hadley 1990).

For the measurement of oxidative DNA damage (lesions/ $10^{6}$ DNA nucleosides), the genomic DNA of brain tissues was extracted by Roche DNA extraction kit, and it was denatured by heating for $3 \mathrm{~min}$ at $95^{\circ} \mathrm{C}$ and then cooled on ice. $100 \mu \mathrm{l} 2 \mathrm{mmol} / \mathrm{l}$ desferrioxamine-B mesylate (DFAM) and $20 \mathrm{mmol} / \mathrm{l}$ acetate buffer $(\mathrm{pH}=5)$ were added to the denaturated DNA. DNA content was analyzed spectrophotometrically at $260 \mathrm{~nm}$ and then hydrolyzed to nucleotides by incubation with $4 \mu \mathrm{l}$ of $3.3 \mathrm{mg} / \mathrm{ml}$ suspension of nuclease $\mathrm{P} 1$. The Tris- $\mathrm{HCl}$ buffer $(\mathrm{pH}=8.5$ ) was added to the mixture and hydrolyzed to the corresponding nucleosides by incubation with calf intestine alkaline phosphatase for $1 \mathrm{~h}$ at $37^{\circ} \mathrm{C}$. After adding up acetate buffer and $50 \mathrm{mmol} / \mathrm{l}$ ethylenedi- 


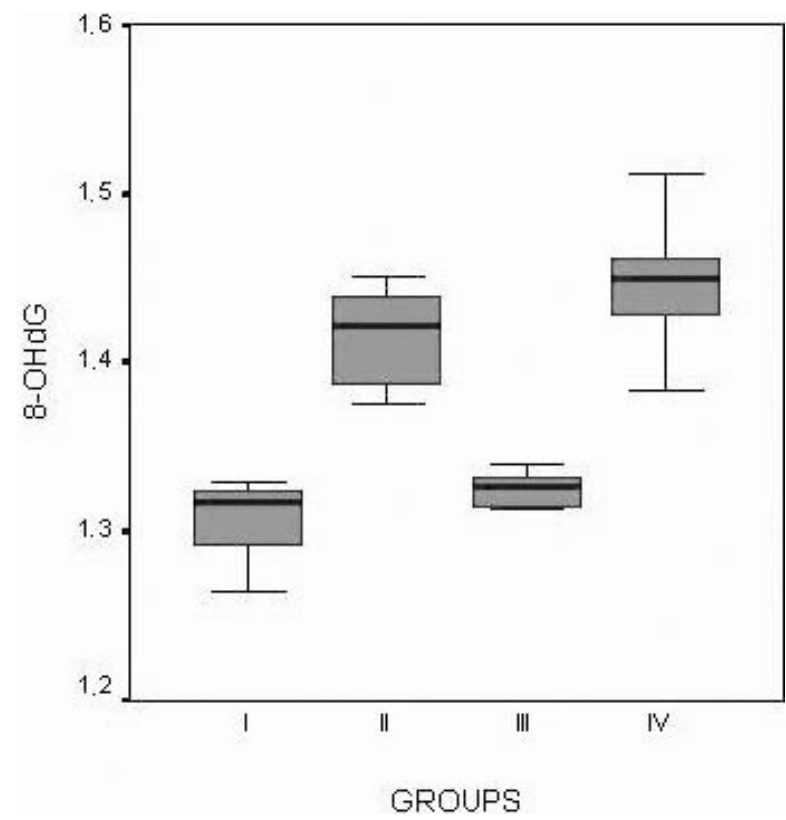

Figure 2. Effects of $1800 \mathrm{MHz}$ GSM-like RFR exposure on 8-OHdG $\left(8-\mathrm{OHdG} / 10^{5} \mathrm{dG}\right)$ content in the brain of New Zealand White rabbits $(n=9)$. Subjects were exposed for 7 days, $15 \mathrm{~min} /$ day. All values are expressed as median (IQR) values. I, nonpregnantcontrol; II, nonpregnant-RFR exposed; III, pregnant-control; IV, pregnant-RFR exposed.

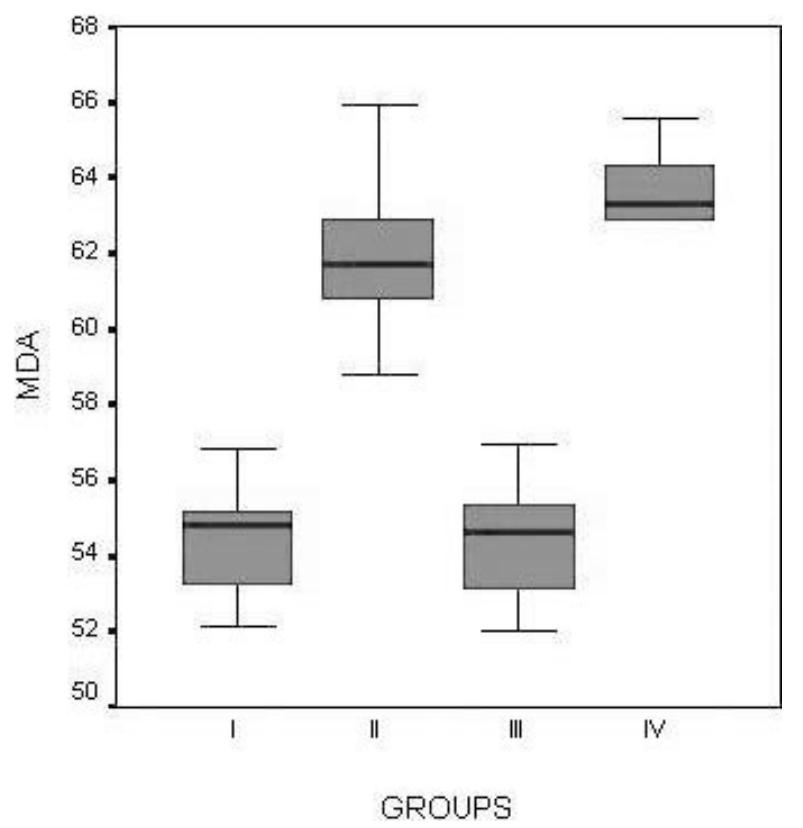

Figure 3. Effects of $1800 \mathrm{MHz}$ GSM-like RFR exposure on MDA (nmol /g wet tissue) content in the brain of New Zealand White rabbits $(n=9)$. Subjects were exposed for 7 days, $15 \mathrm{~min} /$ day. All values are expressed as median (IQR) values. I, non-pregnant-control group; II, non-pregnant-RFR exposed group; III, pregnant-control group; IV, pregnant-RFR exposed group. aminetetraacetic acid (EDTA) /10 mmol/l DFAM solution, the mixture was filtered through a $0.22 \mu \mathrm{m}$ Millipore filter unit (UltraFree, Bedford, MA, USA) and then centrifuged at $10000 \times g$ for $20 \mathrm{~min}$ at $4^{\circ} \mathrm{C}$. Reverse-phase high pressure liquid chromatography/electrochemical detection (HPLC-EC) was performed as described by Floyd et al. (1986). The DNA hydrolysate was injected onto a Waters C18 reverse-phase column $(5 \mu \mathrm{m}, 0.46 \mathrm{~cm} \times 25 \mathrm{~cm}$; Waters Assoc., Milford, MA, USA) at a flow rate of $1 \mathrm{ml} / \mathrm{min}$. The mobile phase was $50 \mathrm{mmol} / \mathrm{l}$ phosphate buffer $(\mathrm{pH}=5.5)$ with $5 \%$ methanol (Halliwell and Dizdaroglu 1992; Hamilton et al. 1999).

The eluant was monitored at $290 \mathrm{~nm}$ for the ultraviolet detection of deoxyguanosine $(\mathrm{dG})$ and at $0.6 \mathrm{~V}$ for the electrochemical detection of 8-OHdG. The system was calibrated with authentic $\mathrm{dG}$ and $8-\mathrm{OHdG}$ standards (Sigma Chemical, St. Louis, MO, USA). dG had a retention time of 10-12 min and 8-OHdG had a retention time of 8.7-13.8 min. Standards were run after every fifth sample for verification, and the data were expressed as the ratio of $8-\mathrm{OHdG}$ to $10^{6} \mathrm{dG}$.

\section{Statistical analysis}

Data analysis was carried out using the SPSS 11.5 statistical package (SPSS, Chicago, IL, USA). The Kruskal-Wallis (nonparametric) test was applied to evaluate differences among all groups while differences between pairs of groups were evaluated by means of the Mann-Whitney test. The results were expressed as median (interquartile range, IQR) values.

\section{Results}

Effect of RFR on DNA damage and MDA level in adult female rabbits

It was found that the brain tissue level of 8 -OHdG increased in both non-pregnant and pregnant-RFR exposed groups [Group II - median $1.42208-\mathrm{OHdG} / 10^{6} \mathrm{dG}$ (IQR 0.0585-0.08) and Group IV - median 1.4490 8-OHdG/10 6 dG (IQR 0.0490-0.13)] with respect to non-pregnant control group [Group I - median 1.3170 8-OHdG/106 dG (IQR 0.0332-0.06)] ( $p<0.001$, Mann-Whitney test) (Figure 2). Significant increase was also found in pregnant-RFR exposed group [Group IV - median $1.44908-\mathrm{OHdG} / 10^{6} \mathrm{dG}$ (IQR 0.0490-0.13)] in comparison to pregnant control group [Group III - median 1.32708 -OHdG/10 6 dG (IQR $0.0215-0.05)](p<0.001$, Mann-Whitney).

Moreover, MDA levels in the same groups [Group II - median $61.7219 \mathrm{nmol} / \mathrm{g}$ wet tissue (IQR 3.8754-7.14) and Group IV - median $63.3184 \mathrm{nmol} / \mathrm{g}$ wet tissue (IQR 3.54607.49 )] were found to increase significantly with respect to non-pregnant controls [Group I - median $54.7823 \mathrm{nmol} / \mathrm{g}$ wet tissue (IQR 2.8269-4.70)] ( $p<0.001$, Mann-Whitney) 
(Figure 3). Significant increase was also found in pregnantRFR exposed group [Group IV - median $63.3184 \mathrm{nmol} / \mathrm{g}$ wet tissue (IQR 3.5460-7.49)] in comparison to pregnant control group [Group III - median $54.6298 \mathrm{nmol} / \mathrm{g}$ wet tissue (IQR 3.2262-4.94)] ( $p<0.001$, Mann-Whitney).

\section{Effect of RFR on DNA damage and MDA level in rabbit} newborns

There was no significant difference in brain tissue 8-OHdG levels of Group VI [median 0.6713 8-OHdG/105 dG (IQR 0.0477-0.06)] and Group V [median 0.6480 8-OHdG/105 dG (IQR 0.0433-0.06)] (Figure 4). Similarly, no difference was found in the MDA levels between newborns of pregnant-RFR exposed [Group VI - median $21.0680 \mathrm{nmol} / \mathrm{g}$ wet tissue (IQR 2.2450-3.82)] and newborns of pregnantcontrols [Group V - median $19.8710 \mathrm{nmol} / \mathrm{g}$ wet tissue (IQR 1.4960-2.70)] (Figure 5).

\section{Effect of RFR on body weight in adult female rabbits}

The weights of all experimental groups were measured. While subjects in Group I and Group II were measured after the last day of exposure, Group III and Group IV were measured once the animals gave birth due to the high risk of miscarriage. No significant difference was found between Group I and Group II. However, there were slight decreases between pregnant-exposed and pregnant-controls with respect to non-pregnant-controls, but the differences were not statistically significant ( $p>0.05$, Mann-Whitney) (Table 1).

\section{Effect of RFR on body weight in rabbit newborns}

The weights of newborns were measured instantly after birth. No significant difference was found between Group V and Group VI ( $p>0.05$, Mann-Whitney) (Table 2).

\section{Discussion and Conclusion}

Experimental data obtained from this study indicated that $1800 \mathrm{MHz}$ GSM-like RFR exposure of non-pregnant and pregnant rabbits for 7 days ( $15 \mathrm{~min} /$ day) resulted in releasing secondary messengers, such as free radicals, leading to oxidative destruction in lipids and DNA molecules. However, no difference was found in the parameters analyzed in the newborns that were intrauterinely exposed to $1800 \mathrm{MHz}$ GSM-like RFR.

Since the results of relevant clinical and epidemiological studies have been inconsistent, possible health effects related to RFR emitted by mobile phones are still unclear and debated. Health effects of RFR are mainly classified as "ther-

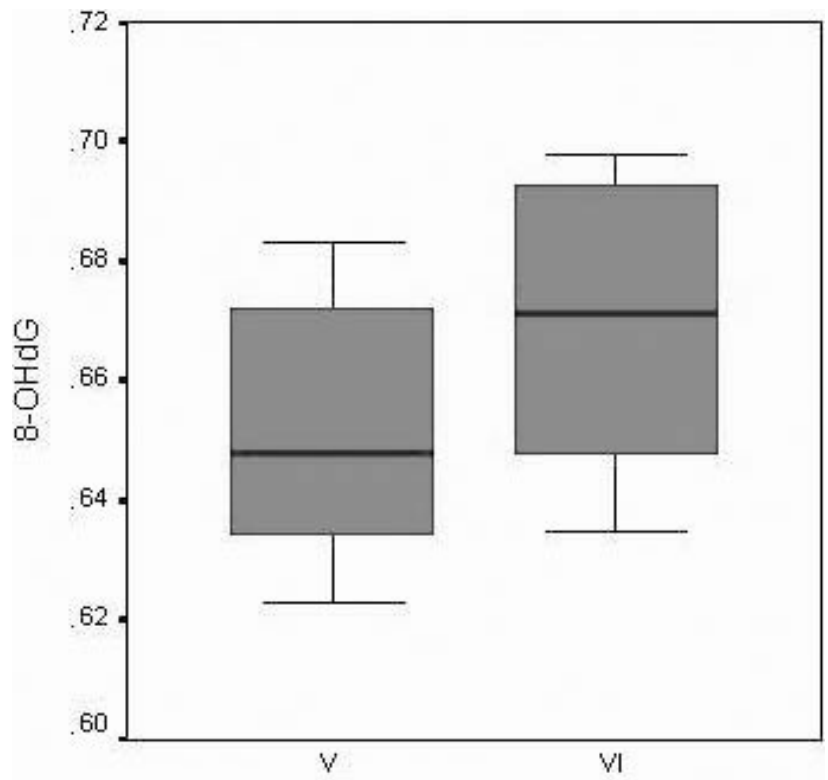

GROUPS

Figure 4. Effects of $1800 \mathrm{MHz}$ GSM-like RFR exposure on 8-OHdG $\left(8-\mathrm{OHdG} / 10^{5} \mathrm{dG}\right)$ content in the brain of newly born New Zealand White rabbits $(n=9)$. All values are expressed as median (IQR) values. V, newborns of Group III; VI, newborns of Group III.

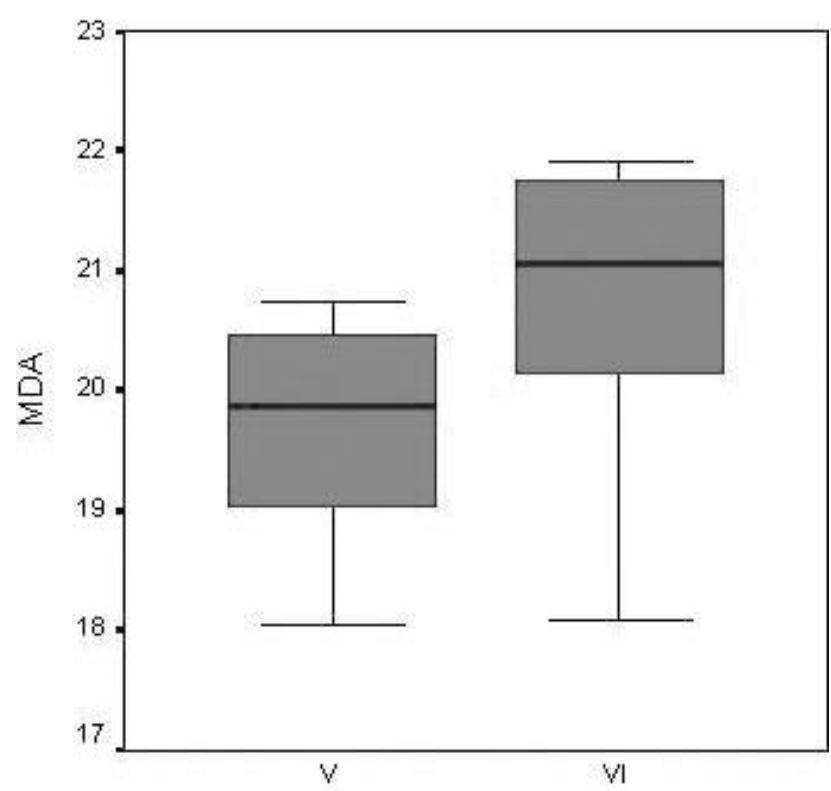

\section{GROUPS}

Figure 5. Effects of $1800 \mathrm{MHz}$ GSM-like RFR exposure on MDA (nmol/g wet tissue) content in the brain of newly born New Zealand White rabbits $(n=9)$. All values are expressed as median (IQR) values. V, newborns of Group III; VI, newborns of Group III. 
Table 1. The weights of non-pregnant and pregnant New Zealand White rabbits after $1800 \mathrm{MHz}$ GSM-like RFR exposure

\begin{tabular}{lc}
\hline Groups & Weight $(\mathrm{g})$ \\
\hline I. Non-pregnant-control & $3825(792-1020)$ \\
II. Non-pregnant-RFR exposed & $3900(575-1150)$ \\
III. Pregnant-control & $3500(450-1300)$ \\
IV. Pregnant-RFR exposed & $3690(467-1381)$ \\
\hline
\end{tabular}

All data are expressed as median (interquartile range, IQR).

Table 2. The weights of newborn rabbits after intrauterine exposure to $1800 \mathrm{MHz}$ GSM-like RFR signals

\begin{tabular}{ll}
\hline Groups & Weight $(\mathrm{g})$ \\
\hline V. Newborns of Group III & $59(21-32)$ \\
VI. Newborns of Group IV & $62(23-35)$ \\
\hline
\end{tabular}

All data are expressed as median (interquartile range, IQR).

mal" and "non-thermal" effects. Reference levels, namely the maximum level of whole body exposure established by ICNIRP for $1800 \mathrm{MHz}$ RFR are $127.3 \mathrm{~V} / \mathrm{m}$ for workers and $58.3 \mathrm{~V} / \mathrm{m}$ for general public. While the current safety standards are based on the thermal effects of RFR in acute exposure, people are chronically exposed to these fields at the non-thermal levels. However, there is still no international safety limit identified specifically for pregnant women. The safety limit for them should be set below the limits for general public or workers in order to protect pregnant women exposed during gestation and baby exposed intrauterinely to RFR. In the present study, the exposure level that we applied $(14 \mathrm{~V} / \mathrm{m})$ is below the standard levels.

In literature, there are studies on the thermal effects of RFR exposure increasing maternal rectal temperature during pregnancy period and the anatomic and physiological changes in offspring related to intrauterine exposure induced by the temperature difference in mother (Berman et al. 1981, 1982, 1984). Female Sprague-Dawley rats were exposed to $2450 \mathrm{MHz}(\mathrm{CW})$ microwave radiation at incident power densities of $28 \mathrm{~mW} / \mathrm{cm}^{2}$ and $40 \mathrm{~mW} / \mathrm{cm}^{2}$ for 100 minutes everyday from the $6^{\text {th }}$ to $15^{\text {th }}$ day of gestation (Berman et al. 1981, 1984). These authors reported that average colonic temperatures increased in both levels of exposure, but mean fetal body weight was reduced after exposure to higher level of power density $\left(40 \mathrm{~mW} / \mathrm{cm}^{2}\right)$. They also reported that maternal rectal temperatures of hamsters exposed to $30 \mathrm{~mW} / \mathrm{cm}^{2}$ for 100 minutes a day from the $6^{\text {th }}$ to $14^{\text {th }}$ day of gestation increased by $1.6^{\circ} \mathrm{C}$. They found that exposure increased the fetal resorptions, decreased fetal body weight and skeletal maturity. They concluded that the hamster fetus may be more susceptible to microwave radiation than the mouse (Berman et al. 1982). In our study, we made similar observations.
Pregnant rabbits were exposed to $1800 \mathrm{MHz}$ GSM-like RFR for 15 min everyday from the $15^{\text {th }}$ to $22^{\text {nd }}$ days of gestation which corresponds to the development period of embryo and transition from embryogenesis to organogenesis. We aimed to observe the rectal temperature changes in pregnant rabbits in order to determine the possible intrauterine effects of RFR at the very beginning of the experiment. However, rabbits are very sensitive animals especially when they are pregnant. They have a tendency to miscarriage when they are stress out. Since measuring rectal temperature may stress the pregnant animals out, we measured the temperature change in only non-pregnant group. After last exposure period, adult rabbits were weighed (Table 1) and a slight decrement in the maternal weight was observed.

In addition to this, no deformation on the extremities and the skeletons of the newborn rabbits was observed during the veterinary controls. Low level of radiation, that rabbits were exposed to, may be one of the reasons for these evidences. Also, the thermoregulatory mechanisms of rabbits may be another factor that is sufficient to compensate slight changes in body temperatures by increasing respiration rate and ear lobe temperature (Fayez et al. 1994). It is suggested that RFR exposure increases the physiological, neurological, cognitive and behavioral changes; it also induces, initiates and promotes carcinogenesis (Gandhi 2005). Higher proportion of DNA damage may be caused by an increase in the formation of free radicals and a deterioration in DNA repair capability and/or efficiency (Kundi et al. 2004). In this manner, free radicals can be classified as one of the most important risk factors which may influence structural biomolecules within the cell. In this study, we discussed that $1800 \mathrm{MHz}$ GSM-like signals may induce DNA base modification through increasing the activation of free radicals.

Recent studies conducted on oxidative stress induced by RFR emitted from mobile phones revealed that it may be caused by an increase in the release of free radicals. Ilhan et al. (2004) determined that mobile phone exposure $(1 \mathrm{~h} /$ day, 7 days) may induce oxidative stress mediated by ROS in brain tissues of the rats. Moreover, Oktem et al. (2005) demonstrated that exposure to mobile phone irradiation during $30 \mathrm{~min} /$ day for 10 days increased tissue MDA levels by suppressing antioxidant enzyme activities. Furthermore, Meral et al. (2007) revealed that RFR generated from cellular phone ( $12 \mathrm{~h} /$ day, 30 days) may produce oxidative stress by increasing MDA levels of brain tissues in guinea pigs. On the contrary, Irmak et al. (2002) reported that mobile phone radiation did not change the MDA level (30 $\mathrm{min} /$ day, 7 days). Likewise, in this study, we found that whole-body $1800 \mathrm{MHz}$ GSM-like RFR exposure for $15 \mathrm{~min} /$ day for a week may affect lipid peroxidation by increasing MDA levels in non-pregnant and pregnant rabbits.

Lai and Singh evaluated DNA damage by measuring DNA strand breaks in brain tissues of rats exposed to $2450 \mathrm{MHz}$ 
microwave radiation at $0.6 \mathrm{~W} / \mathrm{kg}$ for $2 \mathrm{~h}$ a day. (Lai and Singh $1995,1996,1997)$. Results of these studies showed that single and double strand breaks occurred after the exposure. In the same manner, we suggested that the base modification in DNA molecules (8-OHdG) can be induced by the attacks of hydroxyl radical $(\mathrm{OH})$ in both non-pregnant and pregnant animals under RFR exposure.

Although brain tissue of pregnant and non-pregnant rabbits is affected by RFR, there is no effect on $8-\mathrm{OHdG}$ and MDA level analyzed in the newborns. The reason why these parameters did not change in the newborns may be explained by the phenomena of depth of penetration. As RFR propagates in the tissue medium, energy is absorbed by the tissue, resulting in a progressive reduction of RFR as it advances in the tissue. This reduction depends on the depth of penetration, which is the distance in which the power density decreases by a factor of $\mathrm{e}^{2}$ (Polk and Postow 1986). Since the fetus is an inner tissue, more so than the brain of the mother, RFR energy may be reduced to such an extent that fetus is not affected.

Consequently, there hasn't been any research published yet on GSM-like radiation on oxidative DNA and lipid damage in the brain tissue of pregnant animals and their offspring. With this perspective, our results may constitute a reference for the future pregnancy studies. Moreover, it would be beneficial to increase the number of these studies for establishing international standards for the protection of pregnant women under RFR exposure.

Acknowledgements. This work was supported by grants from Gazi University Research Foundation, Project No. 01/2005-07. RFR measurements were performed with the devices granted from Gazi University Research Foundation, Project No. 01/2003-62. We would like to acknowledge our heart-felt thanks to Bilge Has Bıyıklı for her dedicated efforts in editing of English usage and grammar of the manuscript.

\section{References}

Agarwal A., Deepinder F., Sharma R. K., Ranga G., Li J. (2008): Effect of cell phone usage on semen analysis in men attending infertility clinic: an observational study. Fertil. Steril. 89, 124-128; doi:10.1016/j.fertnstert.2007.01.166

Belyaev I. Y. (2005): Non-thermal biological effects of microwaves. Microwave Rev. 11, 13-29

Berman E., Carter H. B., House D. (1981): Observations of rat fetuses after irradiation with $2450 \mathrm{MHz}(\mathrm{CW})$ microwaves. J. Microw. Power 16, 9-13

Berman E., Carter H. B., House D. (1982): Observations of Syrian hamster fetuses after exposure to $2450-\mathrm{MHz}$ microwaves. J. Microw. Power 17, 107-112

Berman E., Carter H. B. (1984): Decreased body weight in fetal rats after irradiation with $2450-\mathrm{MHz}(\mathrm{CW})$ microwaves. Health Phys. 46, 537-542; doi:10.1097/00004032198403000-00004
Berman E., Weil C., Philips P. A., Carter H. B., House D. E. (1992): Fetal and maternal effects of continual exposure of rats to $970 \mathrm{MHz}$ circularly-polarized microwaves. Electromagnetic Biology and Medicine 11, 43-54

Cook M. S., Evans M. D., Dizdaroglu M., Lunec J. (2003): Oxidative DNA damage: Mechanisms, mutation and disease. FASEB J. 17, 1195-1214; doi:10.1096/fj.02-0752rev

Draper H. H., Hadley M. (1990): Malondialdehyde determination as index of lipid peroxidation. Methods Enzymol. 186, 421-431; doi:10.1016/0076-6879(90)86135-I

Fayez I., Marai M., Alnaimy A., Habeeb M. (1994): Thermoregulation in rabbits. (Eds. Baselga M. and Marai I. F. M.). Cahiers Options Méditerranéennes 8, 1. International Conference of rabbit production in hot climates, 1994/ 09/06-08, Cairo (Egypt)

Fejes I., Závaczki Z., Szöllösi J., Koloszár S., Daru J., Kovács L., Pál A. (2005): Is there a relationship between cell phone use and semen quality? Arch. Androl. 51, 385-393; doi:10.1080/014850190924520

Floyd R. A., Watson J. J., Wong P. K., Altmiller D. H. Rickard R. C. (1986): Hydroxyl free radical adduct of deoxyguanosine: Sensitive detection and mechanisms of formation. Free Radical Res. Commun. 1, 163-172; doi:10.3109/ 10715768609083148

Gandhi G. (2005): Genetic damage in mobile phone users: some preliminary findings. Ind. J. Hum. Genet. 11, 99-104; doi:10.4103/0971-6866.16810

Halliwell B., Gutteridge J. M. (2000): Free Radicals in Biology and Medicine. Oxford University Press, New York

Halliwell B., Dizdaroglu M. (1992): Commentary. The measurement of oxidative damage to DNA by HPLC and GC/MS techniques. Free Radical Res. Commun. 16, 75-87; doi:10.3109/10715769209049161

Hamilton M. L., Guo Z. M., Fuller C. D., Van Remmen H., Ward W. F., Austad S. N., Troyer D. A., Thompson I., Richardson A. (1999): A reliable assesment of 8-oxo2-deoxyguanosine levels in nuclear and mitochondrial DNA using the sodium iodide method to isolate DNA. Nucleic Acids Res. 29, 2117-2126; doi:10.1093/nar/ 29.10.2117

rdell L., Mild K. H., Carlberg M. (2002): Case-control study on the use of cellular and cordless phones and the risk for malignant brain tumors. Int. J. Radiat. Biol. 78, 931-936; doi:10.1080/09553000210158038

Hardell L., Mild K. H., Johansson B. (2003): Cellular and cordless telephones and basal cell carcinoma: A case report. Arch. Environ. Occup. H 58, 380-382

Heynick L. N., Merritt J. H. (2003): Radiofrequency fields and teratogenesis. Bioelectromagnetics 24, S174-186; doi:10.1002/bem.10127

Ilhan A., Gurel A., Armutcu F., Kamilsi S., Iraz M., Akyol O., Ozen S. (2004): Ginkgo biloba prevents mobile phone-induced oxidative stress in rat brain. Clin. Chim. Acta 340, 153-162; doi:10.1016/j.cccn.2003.10.012

ICNIRP 1998 Standards: Guidlines for Limiting Exposure to Time Varying Electric and Magnetic Fields (Up to $300 \mathrm{GHz}$ ). International Commission on Non-Ionizing Radiation Protection, Health Physics, 74, 494-522 
IEEE Standards for Safety Levels with Respect to Human Exposure to Radio Frequency Electromagnetic Fields, $3 \mathrm{kHz}$ to 300 GHz. IEEE C95.1-2005

Irmak M. K., Fadillioglu E., Gulec M., Erdogan H., Yagmurca M. Akyol O. (2002): Effects of electromagnetic radiation from a cellular telephone on the oxidant and antioxidant levels in rabbits. Cell. Biochem. Funct. 20, 279-283; doi:10.1002/cbf.976

Kundi M., Mild K. H., Hardell L., Mattsson M. O. (2004): Mobile Telephones and Cancer-A Review of Epidemiological Evidence. J. Toxicol. Environ. Health B Crit. Rev. 7, 351-384; doi:10.1080/10937400490486258

Lai H., Singh N. P. (1995): Acute low-intensity microwave exposure increases DNA single-strand breaks in rat brain cells. Bioelectromagnetics 16, 207-210; doi:10.1002/ bem.2250160309

Lai H., Singh N. P. (1997): Melatonin and a spin-trap compound block radiofrequency electromagnetic radiationinduced DNA strand breaks in rat brain cells. Bioelectromagnetics 18, 446-454; doi:10.1002/(SICI)1521186X(1997) 18:6<446::AID-BEM7>3.0.CO;2-2

Lai H., Singh N. P. (1996): DNA single- and double strand breaks in rat brain cells after acute exposure to low-level radiofrequency electromagnetic radiation. Int. J. Radiat. Biol. 69, 513-521; doi:10.1080/095530096145814

Marinelli F., La Sala D., Cicciotti G., Cattini L., Trimarchi C., Putti S., Zamparelli A., Giuliani L., Tomassetti G., Cinti C. (2004): Exposure to $900 \mathrm{MHz}$ electromagnetic field induces an unbalance between pro-apoptotic and pro-survival signals in T-lymphoblastoid leukemia CCRF-CEM cells. J. Cell Physiol. 198, 324-332; doi:10.1002/jcp.10425
Meral I., Mert H., Mert N., Deger Y., Yoruk I., Yetkin A., Keskin S. (2007): Effects of $900 \mathrm{MHz}$ electromagnetic field emitted from cellular phone on brain oxidative stress and some levels of guinea pigs. Brain Res. 1169, 120-124; doi:10.1016/j.brainres.2007.07.015

Nair V., Cooper C. S., Vietti D. E., Turner G. A. (1986): The chemistry of lipid peroxidation metabolites: crosslinking reactions of malondialdehyde. Lipids 21, 6-9; doi:10.1007/ BF02534294

Oktem F., Ozguner F., Mollaoglu H., Koyu A., Uz E. (2005): Oxidative damage in the kidney induced by $900 \mathrm{MHz}$ emitted mobile phone: protection by melatonin. Arch. Med. Res. 36, 350-355; doi:10.1016/j.arcmed.2005.03.021

Phelan A. M., Lange D. G., Kues H. A., Lutty G. A. (1992): Modification of membrane fluidity in melatonin-containing cells by low-level microwave radiation. Bioelectromagnetics 13, 131-146; doi:10.1002/bem.2250130207

Polk C., Postow E. (1986): CRC Handbook of Biological Effects of Electromagnetic Fields. CRC Press, Boston

Repacholi M. H. (1998): Low-level exposure to radiofrequency electromagnetic fields: health effects and research needs. Bioelectromagnetics 19, 1-19; doi:10.1002/(SICI)1521186X(1998) 19:1<1::AID-BEM1>3.0.CO;2-5

Zhao T. Y., Zou S. P., Knapp P. E. (2007): Exposure to cell phone radiation up-regulates apoptosis genes in primary cultures of neurons and astrocytes. Neurosci. Lett. 412, 34-38; doi:10.1016/j.neulet.2006.09.092

Received: April 18, 2009

Final version accepted: September 17, 2009 